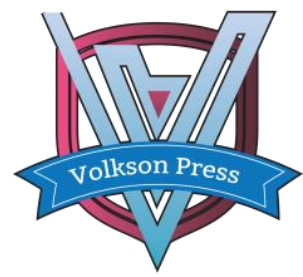

Contents List available at VOLKSON PRESS

Economics \& Management Innovations(EMI)

DOI : http://doi.org/10.26480/icemi.01.2017.154.156

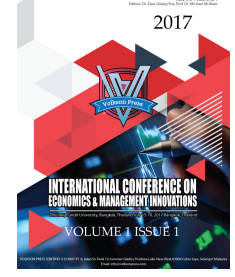

\title{
English Language Competence of Thai School Teachers
}

\author{
Janpha Thadphoothon \\ Faculty of Arts, Dhurakij Pundit University, Bangkok, Thailand \\ Email:janphadpu@gmail.com
}

This is an open access article distributed under the Creative Commons Attribution License, which permits unrestricted use, distribution, and reproduction in any medium, provided the original work is properly cited.

\section{ARTICLE DETAILS}

\section{Article History:}

Received 02 october 2017 Accepted 06 october 2017 Available online 11 october 2017

\section{Keywords:}

Thai teachers, English language competence, Globalization, ASEAN, Thailand 4.0..

\section{ABSTRACT}

The recent policy of the current Thai government to drive Thailand toward the digital economy ( Thailand 4.0) requires that Thai citizens are capable using English to engage in a myriad of online business activities. However, are Thai teachers ready to help turn this policy into reality? This study investigated Thai teachers' English language competence and their use of English. A total of 175 Thai teachers self-assessed their English language ability via questionnaires during March and April 2017. The teachers were those from two public schools under the Bangkok Metropolitan Administration and inservice teachers taking a course leading to a graduate diploma in teaching profession. Results showed that the majority of Thai teachers rated their English performance as being low, but their need to use English was at an average level. Teachers with BAs and those with MAs did not significantly differ in their English language competence and use. It was also revealed that their English language competence affected their ability to integrate English in other subjects. The majority of Thai teachers expressed their desire to undergo English language training and urged greater support from the government and the school administration.

\section{Introduction}

As English is considered a global language and the primary language of international business (Crystal, 2003), Thai governments have been working hard to improve Thai English language skills, realizing that low level English skills are detrimental to a strong and sustainable economy. This realization has been supported by many studies. For example, Education First (2017) studied that better English skills correlate with higher income as well as a better quality of life. In fact, according to Article 34 of the ASEAN Charter, English is the only 'working language', which makes it imperative for Thailand to prepare its citizens in ways that enable them to use English to engage with ASEAN counties and the world at large. However, the Thai ranking in English skills remains low (Education First, 2017). The recent policy of the present Thai government to drive Thailand toward the digital economy or Thailand 4.0 requires that Thai citizens are capable of using English to engage in a myriad of online business and social activities. In addition, the World Bank has urged Thailand to improve its education and the skills of its labor, citing that this is necessary should Thailand wish to break away from the middle-income trap (World Bank, 2017).

Language is not just a system of signs; it is loaded with values and capital. English is a language with symbolic power. In practice, English is indeed one of the keys to national development. So far, Thailand has not been able to significantly upgrade its standing in English competence. A few years before the commencement of the ASEAN community, it was argued that Thai citizens might be at a disadvantage if their English was not improved (Thanthong--Knight and DPA, 2013). To be fair, Thailand has been putting a great deal of energy and effort into the improvement of Thai students' English language skills.

In education, one of the keys to national development is the role of school teachers. The quality of teachers significantly determines the quality of students (The Center for Public Education, 2005). Research shows that Thai school teachers needed more training to develop facilitation skills (Sinlarat and Thadphoothon, 2016). Considering the fact that Thailand has an official policy to improve its quality of education to prepare its citizens for the digital era, the English language ability of the teachers matters. However, Thailand lacks research concerning the English preparedness of Thai school teachers. This research aims to bridge that gap.

The aim of this research is to investigate the English language competence of Thai school teachers and their use of the language.

\section{Literature Review}

\subsection{English in Thailand}

In the past, English was considered an elite language spoken only among the educated and ruling classes (Thadphoothon, 2010). Even though the status of English has gradually changed, English is still the language acquired by people in higher education and in big cities. In Thailand, English is regarded as a foreign language. Despite the fact that English is being taught to primary, secondary, and university students, the overall result has been disappointing. The poor English language ability of Thai students, in general, has been cited as one of the country's weaknesses that hinders its development (Pitsuwan, 2013). The English skills in Thailand are among the lowest in global rankings (Education First, 2017). An earlier review of the literature pointed to several causes including unqualified and poorly-trained teachers leading to poorlymotivated students (Dhanasobhon, 2006; ONEC, 2003, cited in Noomura, 2013: p. 139). Other reasons include poor teaching methods (Punthumasen, 2007), attitudes toward foreign languages (Wiriyachitra, 2004), and Thailand's language policy (Thadphoothon, 2016).

\subsection{Thai School Teachers and Their English Skills}

Previous research showed that Thai school teachers needed more professional development opportunities (Sinlarat and Thadphoothon, 2016). A recent study also noted that Thailand lacked qualified English teachers (Noom-Ura, 2013). Thai school teachers in general are not required to speak English with their students. Increasingly, some Thai schools are offering English programs as alternatives for Thai students, so the language of instruction in some schools is English. Many schools encourage their teachers to integrate English into other subjects.

\section{Method}

The data were collected from 175 Thai school teachers from two public schools under the Bangkok Metropolitan Administration and the inservice teachers taking a course leading to a graduate diploma in teaching. The questionnaires entail six sections: (1) general information, (2) selfassessment of English competence, (3) English language needs, (4) Language Use, (5) Attitudes and Beliefs about the English Language, and (6) Obstacles to Language Development. The data collection was carried 
out in March and April 2017. The research tools were the questionnaires. Data were analyzed using basic descriptive statistics, namely, frequency, mean, percent, standard deviation, andT-test.

\section{Findings}

Table 1: Basic data of the respondents

\begin{tabular}{|c|l|c|c|}
\hline \multicolumn{2}{|c|}{ Characteristics } & Number & Percent \\
\hline Gender & Female & 131 & 74.86 \\
\cline { 2 - 4 } & Male & 44 & 25.14 \\
\hline \multirow{4}{*}{ Age } & Total & 175 & 100 \\
\hline \multirow{5}{*}{ Education } & $18-27$ years old & 50 & 28.57 \\
\cline { 2 - 4 } & 28-37 years old & 63 & 36.00 \\
\cline { 2 - 4 } & $38-47$ years old & 32 & 18.29 \\
\cline { 2 - 4 } & $48-57$ years old & 20 & 11.43 \\
\cline { 2 - 4 } & 58-or older & 10 & 5.71 \\
\hline \multirow{3}{*}{} & Total & 175 & 100 \\
\cline { 2 - 4 } & BA & 139 & 79.43 \\
\cline { 2 - 4 } & MA & 34 & 19.43 \\
\cline { 2 - 4 } & Doctoral & 175 & 1.14 \\
\hline \multicolumn{2}{|c|}{ Total } & & \\
\hline
\end{tabular}

Table 1 shows the basic characteristics of the teacher respondents. Of the 175 teachers, 131 of them $(74.86 \%)$ were female. The majority of the teachers were between 18-47 (82.86\%). Only10

(5.71\%) were 58 or above. In terms of education, the majority of the respondents were BA holders (79.43\%). Only two of them (1.14\%) held a doctoral degree.

\section{Table 2: English Competence of the Teachers}

\begin{tabular}{|l|c|l|r|}
\hline Domain & $\mathrm{N}$ & Mean & S.D. \\
\hline Speaking skills & 175 & 2.45 & .855 \\
\hline Listening skills & 175 & 2.51 & .823 \\
\hline Reading skills & 175 & 2.67 & .789 \\
\hline Writing skills & 175 & 2.50 & .809 \\
\hline Grammar \& Vocabulary & 175 & 2.43 & .776 \\
\hline Translation skills & 175 & 2.44 & .855 \\
\hline \multicolumn{1}{|c|}{ Average } & 175 & 2.50 & .74 \\
\hline \multicolumn{1}{|c|}{} & & & \\
\hline
\end{tabular}

Table 2 shows the respondents' English language competence based on their self-assessment. On average, their English language ability was rated to be at a low level (Mean $=2.50$ ).

Table 3: Differences between Exiting English Competence and Demand

\begin{tabular}{|c|c|c|c|c|c|c|}
\hline & Pair & $\mathrm{N}$ & Means & SD & $\mathrm{T}$ & Sig. (2-tailed) \\
\hline 1 & Speaking skills & 175 & 2.45 & .85 & -10.31 & .00 \\
\hline & Need for speaking skills & 175 & 3.30 & 1.10 & & \\
\hline 2 & Listening skills & 175 & 2.51 & .82 & -8.94 & .00 \\
\hline & Need for listening skills & 175 & 3.26 & 1.11 & & \\
\hline 3 & Reading skills & 175 & 2.67 & .78 & -6.88 & .00 \\
\hline & Need for readingskills & 175 & 3.26 & 1.08 & & \\
\hline 4 & Writing skills & 175 & 2.50 & .80 & -6.75 & .00 \\
\hline & Need for writing skills & 175 & 3.09 & 1.10 & & \\
\hline 5 & Translation skills & 175 & 2.44 & .85 & -8.99 & .00 \\
\hline & Need for translationskills & 175 & 3.19 & 1.14 & & \\
\hline
\end{tabular}

\section{Table 3 shows the mean differences between the existing English}

competence and their need touse those skills. For each pair compared, it was found that the mean was significantly different at the .01 level.
When English teachers and non-English teachers were compared, it was found that Thai English and Non-English teachers differed in their English language competence and language use. English teachers said they were more competent and used more English.

Table 4: English Use and Needs between Low and High Competence Teachers

\begin{tabular}{|l|l|c|c|c|c|}
\hline \multicolumn{1}{|c|}{ English Use } & $\mathrm{N}$ & Means & $\mathrm{SD}$ & $\mathrm{T}$ & Sig. (2-tailed) \\
\hline Low Competence & 90 & 1.95 & .69 & -8.47 & .00 \\
\hline High Competence & 16 & 3.53 & .65 & & \\
\hline English Needs & $\mathrm{N}$ & Means & $\mathrm{SD}$ & $\mathrm{T}$ & Sig. (2-tailed) \\
\hline Low Competence & 90 & 2.88 & 1.00 & -14.36 & .00 \\
\hline High Competence & 16 & 4.18 & .65 & & \\
\hline
\end{tabular}

It was found that teachers with a higher English competence reported that they used English more and said that they needed to use English more frequently when compared with teachers with a lower level of language competence.

Table 5: English competence and English use

\begin{tabular}{|l|l|l|l|c|c|}
\hline I like English. & $\mathrm{N}$ & Means & SD & $\mathrm{T}$ & Sig. (2- tailed) \\
\hline Low Competence & 90 & 3.58 & .99 & -3.50 & .00 \\
\hline High Competence & 16 & 4.50 & .81 & & \\
\hline C conversation with foreign teachers. & $\mathrm{N}$ & Means & SD & $\mathrm{T}$ & Sig. (2- tailed) \\
& & & & & \\
\hline Low Competence & 90 & 1.98 & .971 & -8.37 & .00 \\
\hline High Competence & 16 & 4.19 & .981 & & \\
\hline to other subjects that I teach. & $\mathrm{N}$ & Means & SD & $\mathrm{T}$ & Sig. (2- tailed) \\
& & & & & \\
\hline
\end{tabular}

\begin{tabular}{|c|r|c|c|c|c|}
\hline \multicolumn{1}{|l|}{ Table 5.cont } \\
\cline { 1 - 4 } Low Competence & 90 & 2.47 & 1.030 & -5.18 & .00 \\
\hline High Competence & 16 & 3.88 & .806 & & \\
\hline I speak with my students in English. & $\mathrm{N}$ & Means & SD & T & \multirow{2}{*}{ Sig. (2-tailed) } \\
\hline Low Competence & 90 & 2.20 & .93 & -6.98 & .00 \\
\hline High Competence & 16 & 3.94 & .77 & & \\
\hline
\end{tabular}

Table 5 shows the profiles of teachers with low and high levels of English competence. In terms of liking, the teachers with high-level competence of English had more positive attitudes toward English $($ Mean $=4.50)$. When compared with teachers with lower English language competence, teachers with avhigh level of English competence said they engaged more in conversations with foreign teachers, communicated more in English with their students, and integrated more English into other subjects.

\section{Discussions}

\subsection{English language competence}

Based on self-assessment, the English language competence of Thai school teachers was the result of their own evaluation of language ability. One hundred and seventy-five Thai school teachers rated their own English competence as being at a low level (Mean $=2.50)$. This perception may not represent the total population of Thai school teachers across the country (about 400,000 of them). However, the result was supported by the evaluation of Thai citizens' English proficiency by Education First (2017), which ranked Thailand in the lower quartiles. This finding may not be considered a big surprise, considering the fact that even among Thai English teachers, English proficiency was found to be a source of anxiety (Klanrit and Sroinam, 2012).

\subsection{English language use}

The use of the English among Thai school teachers was strictly limited to the classroom context. Thai school teachers rarely used English to write letters. They rarely read English books, reports, or emails. They also 
rarely did translation work and conversed in English with other Thai teachers. Males and females did not differ significantly in terms of the frequency of their English use. However, Thai English teachers used more English than school teachers. An earlier study showed that Thai English teachers were reluctant to use English in the classroom (Klanrit and Sroinam, 2012) and grammar- translation is still dominant instructional model (Punthumasen, 2007).

It was revealed that the teachers' English competence was behind their need to use the language. This may point to a big gap in professional development (Sinlarat and Thadphoothon, 2016). The teachers also requested that the government and the school authorities provide greater opportunities for them to improve their English language skills. A heavy workload and time were cited as the primary obstacles to improving their language development.

\subsection{Effects of English language competence}

Teachers with a high level of English competence were those who were keen to integrate English into the subjects they taught and were active in language use. They chatted more in English with students, read more books, and conversed in English with foreign teachers. As for teachers with a low level of competence, they recognized that they had problems with their English; their attitudes towards English were neutral. When they speak English, they were less confident compared with those with higher English competence.

\subsection{English Language Training and Development}

It was clear from this research that Thai school teachers need more training to improve their English skills. However, they said that they had no time because they had a lot of work to do. Therefore, authorities and policy makers should support them with time and resources so that they have opportunities to develop their English. In addition, since school teachers believe that teachers should speak in English to students as often as possible, it is feasible to encourage both teacher and students to engage more in academic activities in English. Teachers believe that the best way to learnEnglish is to practice the language. With the advent of the Internet and smartphone technologies, there are even more opportunities to learn English. Indeed, Thai school teachers can learn English on the go, through applications on smartphones.

\section{Conclusion}

This study investigated Thai school teachers' English language competence and their use of English. Based on the self-assessment of 175 teachers, it was found that their level of English competence was at a low level, but their need to use the language was at an average level. Their use of English was limited by their humble proficiency. Teachers with high competence conversed more in English with their students and infused more English in the subjects they taught. Teachers would like the authorities to support them in the development of their English language skills. The three important obstacles hindering them from developing their language skills are the workload, available time, and opportunities to use English.

\section{References}

[1] Crystal, D. (2003). English as a global language (2nd ed.). Cambridge, UK ; New York: Cambridge University Press. [2] Education First $(2017$
June 2). The world's largest ranking of countries by English skills. Available online athttp://www.ef.co.th/epi/

[3] Klanrit, P. and Sroinam, R. (2012). EFL Teacher's Anxiety in Using English in Teaching in the Language Classroom in International Journal of Social Science and Humanity, Vol. 2, No. 6, pp. 493-496.

[4] Noom-ura, S. (2013) English-Teaching Problems in Thailand and Thai Teachers' Professional Development Needs English Language Teaching; Vol. 6, No. 11; 2013 pp. 139-147.

[5] Pitsuwan, S. (2013, September 16). Improving English skills is vital: Surin. Available online at http://www.nationmultimedia.com/news/national/aec/30214891

[6] Punthumasen, P. (2007, December 12-14). International program for teacher education: An approach to tackling problems of English education in Thailand. The $11^{\text {th }}$ UNESCO-APEID International Conference. Bangkok, Thailand.

[7] Sinlarat, P. and Thadphoothon, J. (2016, February). Integrating Transversal Competencies in Education Policy and Practice (Phase III): Thailand. Paper presented at the 2016 ERI-NET Annual Meeting, 22-24 February 2016, Tokyo, Japan.

[8] Thadphoothon, J. (2014) A Study of Educational Readiness and preparation of the nine selected ASEAN member states in Response to Asean integration by 2015 A.D. Available online at http://www.dpu.ac.th/dpurc/research-352

[9] Thadphoothon, T. (2010). Asian Englishes : History, Identity, and Power in The Asian Way: New Directions for Management. Bangkok: DPU ResearchCenter.

[10] Thadphoothon, J. (2016). “Thailand's Language Policy: Can it lead to an equal society?" Paper presented at the $5^{\text {th }}$ International Conference on Advancement of Development Administration 2016 - Social Sciences and Interdisciplinary Studies (the 5th ICADA 2016 -ISIS), The National Institute of Development Administration (NIDA), angkok, Thailand.

[11] The World Bank (2017, April). "Overview of Thailand". Available online at http://www.worldbank.org/en/country/thailand/overview

[12] Thanthong--Knight, S. and DPA (2013, March 19)." Thais' poor English to hurt job prospects in Asean community" Available online at http://m.bangkokpost.com/news/special- reports/501904/thais-poorenglish-to-hurt-job-prospects-in-asean-community

[13] The Center for Public Education (2005, November 1). Teacher quality and student achievement: Research review. Available online at http://www.centerforpubliceducation.org/MainMenu/Staffingstudents/Teacher-quality-and-student-achievement-Ata-glance/Teacher-quality- and-student-achievement-Researchreview.html

[14] Wiriyachitra, A. (2004). "English language teaching and learning in Thailand this decade" Available online at http://www.reo14.moe.go.th/en/images/upfile/english\%20language \%20teaching\%20and\%20lea rning\%20in\%20thailand.pdf 